\title{
Electric Fencing Reduces Coyote Predation on Pastured Sheep
}

\author{
SAMUEL B. LINHART, JERRY D. ROBERTS, AND GARY J. DASCH
}

\begin{abstract}
Field tests to evaluate electric fencing for protecting pastured sheep from coyote predation were conducted in North Dakota and Kansas in 1977 and 1978. In 1979, 37 western sheep producers using electric fences to exclude coyotes were interviewed and relevant data were recorded and analyzed. An all-electric 12-wire, 168-cm-high fence with alternately charged and grounded wires spaced 13 and $15 \mathrm{~cm}$ apart stopped ongoing coyote predation on the two North Dakota test sites. Four or five strands of electrified wire, offset $13 \mathrm{~cm}$ from existing woven and barbed wire sheep fences, effectively prevented further coyote predation at two Kansas sites. Sheep producers interviewed expressed a high to moderate degree of satisfaction with the use of electric fencing as a coyote management technique. However, sheep management practices on two-thirds of the ranches remained unchanged after electric fence installation and nearly all producers continued to use other control methods. Sixty percent of the producers stated that they experienced some type of maintenance problems but many of these problems may have been due to poor construction techniques or a failure to check their fences periodically. ost-benefit factors associated with the use of electric fencing, study limitations, and further research needs are discussed.
\end{abstract}

Woven or "net" wire fences have been used for many years as perimeter barriers or drift fences to exclude coyotes (Canis latrans) from sheep pastures (for a review, see Thompson 1979). However, the installation of electric fencing for this purpose has been limited and only within recent years have reports been published describing this approach. These reports have (I) outlined the mechanics of constructing electric fencing without reference to data indicative of their effectiveness (Shelton 1977, Henderson 1978, Gates 1978); (2) presented data on their effectiveness (or lack thereof) only when tested against captive coyotes confined to penned areas (Thompson 1976, 1979; Gates et al. 1978), or (3) evaluated electric fencing techniques and materials that have been largely replaced by more advanced technology (Larson et al. 1975; Wallace 1975; Thompson 1976, 1979). Most recently, Dorrance and Bourne ( $\| 980)$ presented convincing field data indicating that electric fencing eliminated or sharply reduced sheep losses to coyote predation.

All three authors are employed by the U.S. Fish and Wildlife Service, Denve wildlife Research Center, Building 16. Federal Center, Denver, Colorado 80225

We thank R. Banning, C. Bentrup, L. Erhardt, E. Gnadt, F. Gnadt, J. Huff, R. Price, and L. Stewart, sheep producers in North Dakota and Kansas who cooperated with us and permitted field tests to be run on their ranches. Fish and Wildlife Service ADC personnel in North Dakota, especially W. Pfeifer, E. Pittsley, R. Severson, and J. She help of cooperating producers, and provided on-site assistance, as did E. Boggess, B. Brown, and F. Henderson, Kansas State University. R. Felton, N. Fischer, T. Rose, and $O$. Wahl helped construct test enclosures. J. Beyer responsibly monitored the North Dakota tests, recorded data, and made valuable suggestions and recommendations. L. Kolz and R. Johnson, Denver Wildlife Research Center, measured and evaluated a number of different fence chargers and otherwise provided electronic support. E. Boggesis, D. de Calesta, J. Gallagher, F. Henderson, J. Henderson, R. Nass, E. Pearson, R. Piesse, A. Snell, J. Tigner, and $F$. Turkowski reviewed a draft of our questionnaire and made many helpful suggestions. A. Kriwox interviewed sheep producers in the states of Oregon and Washingt on who were using electric fencing on their ranches at the time of our survey. Finally, we acknowled ge the assistance of those electric fencing distributors, wildlife extension specialists, county extension agents, and Fish and Wildlife Service employees who provided us with the names of producers we interviewed, as well as the producers themselves who freely offered the information required to conduct the survey.

Manuscript received September 29, 1980.
New Zealand "energizers" (fence chargers) and electric fencing technology developed in Australia and New Zealand were introduced into the United States in about 1976. Their a vailability' and aggressive sales promotion within this country stimulated interest in electric fencing, both for livestock management and for excluding coyotes and other predators from sheep pastures. Because electric fencing is more widely used in Australia and New Zealand, and since fencing technology in those countries appeared more advanced than that available in the U.S., we elected to use imported equipment and fencing practices for building our test fences.

We selected a 12-volt, battery-operated, New Zealand energizer (Gallagher Model E-12) for our field tests. Laboratory measurements indicated this charger was capable of driving greater than 8 amperes of peak current into a $500 \mathrm{ohm}$ resistive load. As the magnitude of current is related to the intensity of electrical shock, the New Zealand energizer produces a very intense repelling stimulus.

Under New Zealand regulations, the maximum voltage from an energizer cannot exceed 5000 volts. There are many fence chargers marketed in the U.S. which produce voltages in excess of 15,000 volts, but the limited number of chargers that we tested indicated that, under simulated load conditions, these high voltage chargers actually delivered less current than the 5000 volt New Zealand model. The reason for this difference is due to an electrical design which allows the high voltage units to dissipate their energy internally rather than delivering it to the external load. Fence chargers characterized by this high internal loss are called high output impedance chargers in contrast to the low impedance models produced in New Zealand and Australia. Proponents of the high impedance chargers often express concern as to the human shock hazard imposed by the low impedance devices. To our knowledge, there has never been a fatality from a low impedance energizer produced under the manufacturing regulations imposed by New Zealand and Australia as well as several European countries. In fact, certain New Zealand fence chargers have recently been approved by Underwriters' Laboratories, Inc. in the United States.

Our field studies of electric fencing were conducted from 1977 to 1979 and consisted of three phases: a test to measure the efficacy of an all-electric fence for excluding sheep-killing coyotes, an evaluation of electrified wires offset from existing woven wire sheep fences, and a field survey involving personal interviews with a sample of western sheep producers who were currently using electric fencing to protect their pastured sheep flocks.

\section{All-electric Fence}

\section{Methods}

Two ranches in south-central North Dakota having a history of

'Kiwi Fence Systems, Inc., RD 5, Box 122, Waynesburg, Penn. 15370; Koppers Co. Inc., Koppers Building, Pittsburgh, Penn. 15219; Live Wire Products, P.O. Box 150 Grass Valley, Calif.; Snell Systems, Inc., 10910 Wye Drive, San Ant onio, Tex. 78217 Henry \& Cornelia Swayze, Brookside Farm, Tunbridge, Vt. 05077; and Waterford Corp., P.O. Box 1513. 1449 Riverside. Fort Collins. Colo. 80522. Most or all of these companies can provide detailed instructions for installing electrical fences. Use of trade names does not constitute endorsement of commerical products by the U.S Government. 
chronic coyote depredations were used as test sites in 1977. Two sites a few hundred meters distant from each other were fenced on Ranch A. One enclosure ( 1.46 ha or 3.51 a) consisted of a barbed wire fence strung on metal $\mathrm{T}$-posts adequate to retain lambs but not to exclude coyotes. This fence was designated as Fence I; its configuration (as are all other test fences) is described in Table 1. The second enclosure (fence $2,1.38$ ha or 3.41 a) was an all-electric fence built according to instructions provided by the New Zealand manufacturers and U.S. importers of electric fencing equipment. It consisted of tightly stretched (700-900 newtons or 150-200 lb of force) $2.5 \mathrm{~mm}$ (12-1/2 gauge) high-tensile, smooth electric fencing wire clipped to $2.13 \mathrm{~m}$ ( $7 \mathrm{ft}$ ) fiberglass $\mathrm{T}$-posts driven $46 \mathrm{~cm}$ ( $18 \mathrm{in}$.) into the earth. Conventional wood corner brace posts were used, but an additional brace post was positioned inward from each corner at a $45^{\circ}$ angle so as to accommodate the highly tensioned wires. Ceramic insulators were wired to all corner posts and in-line wire strainers were tied into all wires to adjust and maintain the correct tension. An insulated lead connecting all grounded wires was clamped to two $5.1-\mathrm{cm}$ dia ( 2 in.) grounding rods located $1.8 \mathrm{~m}$ $(6 \mathrm{ft})$ apart and driven about $2 \mathrm{~m}$ into the earth. The insulated lead connecting all charged wires was clamped to the energizer.
The first electric fence configuration evaluated on Ranch A was a six-strand fence $76 \mathrm{~cm}$ (30 in.) high with alternate wires charged and grounded (Fence 2). The above configuration was later modified by adding a charged "outrigger" or "trip" wire $25 \mathrm{~cm}$ (10 in.) high and $51 \mathrm{~cm}$ (20 in.) out from the test fence and supported on shortened sections of fiberglass T-post (Fence 3 ). The last configuration tested on Ranch $A$ involved removal of the trip wire and the addition of six more wires above the original 76-cm high fence (Fence 4). This resulted in a 12-wire, $168-\mathrm{cm}$ (66 in.) high enclosure (Fig. 1) essentially identical to that described by Gates (1978) and Gates et al. (1978) but lacking a trip wire.

Two adjacent enclosures were also constructed at a second North Dakota test site (Ranch B). The first (1.50 ha or 3.70 acres) was of barbed wire (Fence 1 ) and the second ( 1.00 ha or 2.41 acres) was a 12-wire, 168-cm high electric fence (Fence 4). Fences 2 and 3 were not evaluated at this site because of our earlier experience with these configurations on Ranch $\mathrm{A}$.

The test procedure on both ranches was to document coyotc predation on lambs in the barbed wire enclosure and then move the lambs into the adjacent electric fence enclosure. If the electric fence failed to stop predation, we made modifications until predation

Table 1. Fence configurations used in North Dakota and Kansas tests, 1977-1978.

\begin{tabular}{|c|c|c|c|c|}
\hline Test numbers & Test ranch & Wire type & Spacing intervals ${ }^{\prime}$ & Charging configuration \\
\hline $1^{2}$ & $A$ and $B$ & Barbed & $\begin{array}{l}5 \text { strands spaced at } 15,30,48,71 \text {, and } 104 \mathrm{~cm} \\
\text { above ground level }(6,12,19,28 \text {, and } 41 \mathrm{in} .) \text {. }\end{array}$ & Not charged. \\
\hline 2 & A & Electric & $\begin{array}{l}6 \text { strands spaced at } 13,25,38,51,64 \text {, and } 76 \mathrm{~cm} \\
\text { above ground level } 5,10,15,20,25 \text {, and } 30 .) \text {. }\end{array}$ & Alternate + and - charged wires; bottom + wire. \\
\hline 3 & A & Electric & $\begin{array}{l}\text { Identical to Fence } 2 \text { but with single electric } \\
\text { "trip" wire positioned } 25 \mathrm{~cm}(10 \mathrm{in.}) \text { above } \\
\text { ground level and } 51 \mathrm{~cm}(20 \mathrm{in} .) \text { out from Fence } 2 .\end{array}$ & Identical to Fence $2 ;+$ charged "trip" wire. \\
\hline 4 & $A$ and $B$ & Electric & $\begin{array}{l}12 \text { strands of electric wire. Bottom } 6 \text { wires } \\
\text { identical to Fence } 2 \text {; top } 6 \text { wires spaced at } 91 \text {, } \\
107,122,137,152 \text {, and } 168 \mathrm{~cm} \text { above ground } \\
\text { level }(36,42,48,54,60 \text {, and } 66 \text { in.). }\end{array}$ & Alternate + and - charged wires; bottom + wire \\
\hline $5^{2}$ & C & $\begin{array}{l}\text { Woven \& } \\
\text { barbed wire }\end{array}$ & $\begin{array}{l}\text { Standard woven wire }(6-35-12-121 / 2) \text { erected } \\
\text { on metal T-posts. Bar spacings were } 14,29,47 \text {, } \\
67, \text { and } 90 \mathrm{~cm} \text { above ground level }(5.5,11.5 \text {, } \\
18.5,26.5,35.5 \text { in.). Two strands of barbed wire } \\
\text { spaced at } 100 \text { and } 110 \mathrm{~cm}(39.5 \text { and } 43.5 \text { in.) above } \\
\text { ground level. }\end{array}$ & Not charged. \\
\hline 6 & $\mathrm{C}$ & $\begin{array}{l}\text { Woven \& } \\
\text { barbed wire } \\
\text { with offset } \\
\text { electric wires }\end{array}$ & $\begin{array}{l}\text { Identical to Fence } 5 \text { but with } 4 \text { electric wires } \\
\text { off-set } 13 \mathrm{~cm} \text { ( } 5 \text { in.) from woven and barbed } \\
\text { wire fence. Off-set wires spaced at } 13,38,56 \text {, } \\
\text { and } 122 \mathrm{~cm} \text { above ground level }(5.0,15.0,22.0 \\
\text { and } 48.0 \mathrm{in.})\end{array}$ & - woven and barbed wires; + electric wires \\
\hline 7 & $\mathrm{C}$ & $\begin{array}{l}\text { Woven \& } \\
\text { barbed wire } \\
\text { with offset } \\
\text { electic wires }\end{array}$ & $\begin{array}{l}\text { Identical to Fence } 6 \text { but with } 5 \text { th electric wire } \\
\text { added at } 79 \mathrm{~cm} \text { above ground level }(31 \mathrm{in.}) \text {. }\end{array}$ & - woven and barbed wires; + clectric wires. \\
\hline $8^{2}$ & $\mathrm{D}$ & $\begin{array}{l}\text { Woven and } \\
\text { barbed wire }\end{array}$ & $\begin{array}{l}\text { Standard woven wire }(9-39-12-121 / 2) \text { erected } \\
\text { on metal T-posts. Bar spacings were } 8,17,27 \text {, } \\
38,51,65,80, \text { and } 98 \mathrm{~cm} \text { above ground level } \\
(3.0,6.5,10.5,15.0,20.0,25.5,31.5,38.5 \mathrm{in} .) \text {. } \\
\text { One strand of barbed wire spaced at } 110 \mathrm{~cm}(43.5 \\
\text { in.) above ground level. }\end{array}$ & Not charged. \\
\hline 9 & $\mathrm{D}$ & $\begin{array}{l}\text { Woven \& } \\
\text { barbed wire } \\
\text { with offset } \\
\text { electric wires. }\end{array}$ & $\begin{array}{l}\text { Identical to Fence } 8 \text { but with } 4 \text { electric wires offset } \\
13 \mathrm{~cm} \text { ( } 5 \text { in.) from woven and barbed wire fence. } \\
\text { Offset wires spaced at } 15,46,71 \text {, and } 127 \mathrm{~cm} \text { above } \\
\text { ground level }(6,18,28 \text {, and } 50 \text { in.). }\end{array}$ & - woven and barbed wires; + electric wires. \\
\hline 10 & $\mathrm{D}$ & $\begin{array}{l}\text { Woven \& } \\
\text { barbed wire } \\
\text { with offset } \\
\text { electric wires. }\end{array}$ & $\begin{array}{l}\text { Identical to Fence } 9 \text { but with only the two } \\
\text { bottom wires ( } 15 \text { and } 46 \mathrm{~cm} \text { in hgt.) in place and } \\
\text { electrified. }\end{array}$ & - woven and barbed wires; + electric wires. \\
\hline
\end{tabular}

\footnotetext{
'Actual wire spacings varied slightly from those shown in table due to variations in ground contours, wire tensions, and pre-notched fiberglass T-posts.
}

iSheep confined within these fences were used to document coyote kills prior to evaluation of electric fences or wires. 


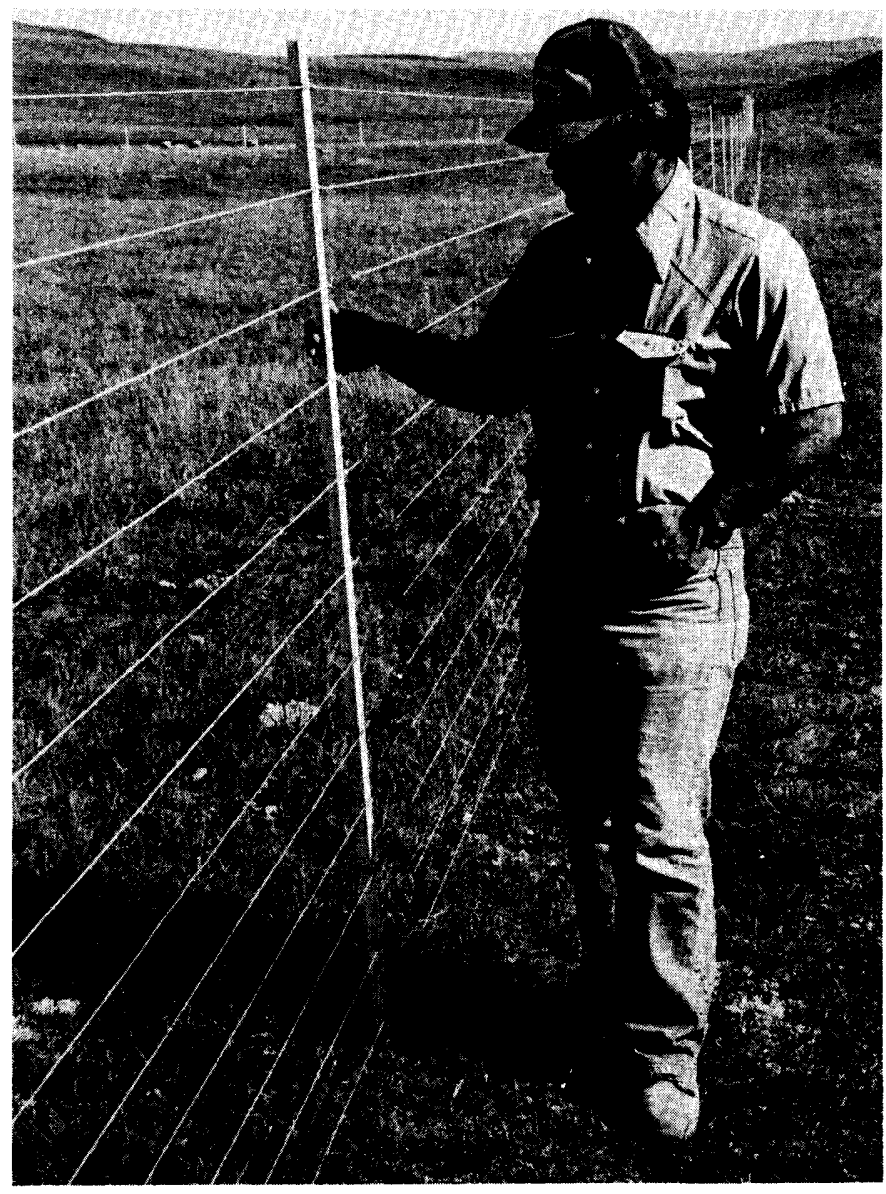

Fig. 1. A 12-wire, 168-cm high electric fence tested in North Dakota. This fence effectively excluded covotes.

ceased. Specifically, this procedure was carried out by placing 10 lambs in each of the two barbed wire enclosures on Ranches $A$ and $B$ and checking them every other day for coyote kills. Lambs found dead within the enclosures were examined and coyote kills determined using criteria similar to those described by Rowley (1970), Henne (1975), and Bowns (1976). Coyote-killed lambs and those that died from other causes were replaced, as necessary, to maintain a total of 10 live lambs per enclosure. When a total of 10 or more "baseline" kills had occurred, the remaining live lambs were removed from the barbed wire enclosure and the adjacent electric fence enclosure was "stocked" with 10 lambs and electrified. These lambs were then checked every other day for further coyote kills. Lambs confined within fence configurations that effectively excluded coyotes were monitored for 60 days, at which time tests were terminated.

Test enclosures used in 1977 and for trials in 1978 (discussed later) varied somewhat in size (0.93-1.75 ha or 2.25-4.2 acres) because of variations in vegetation, slope, and subsurface rock or hard pan at each site.

\section{Results}

Results of the 1977 field tests in North Dakota are shown in Figure 3. On Ranch A, lambs were confined within the barbed wire enclosure (Fence 1) for 22 days. Coyotes began killing on day 5 and continued intermittently until day 22 , by which time a total of 16 lambs had been attacked. The remaining live animals were removed from this enclosure and 10 lambs were placed in the adjacent six-wire, 76-cm-high electric fence enclosure (Fence 2). Lambs remained in Fence 2 for 20 days but nine were killed between days 16 and 20 . An off set "trip" wire (Fence 3 ) was then stretched around the enclosure. The trip wire failed to deter predation (four lambs killed on day 4) and it was removed and the electric fence was raised to $168 \mathrm{~cm}$ by the addition of six more wires
(Fence 4). This configuration stopped predation for the next 60 days, at which time the test on Ranch $A$ was terminated.

On Ranch B, coyote kills totaled 17 lambs confined within Fence I over a 68-day period. Kills began on day 28 and continued until the lambs were moved into the nearby 12-wire, 168-cm electric fence enclosure (Fence 4). No kills occurred for the next 60 days and the test was therefore eneded.

\section{Offset Electric Wires}

\section{Methods}

Off set electric wires strung on the outside of existing woven wire sheep fences were evaluated as a coyote exclusion technique in 1978. Two sheep ranches, one in southwestern Kansas and the second in northeastern Kansas, were selected as test sites. Both ranches had a history of chronic coyote depredations and both had sheep killed by coyotes in late spring 1978, just before initiation of our field tests. A single woven wire sheep fence enclosure was constructed on each ranch. The enclosure (1.75 ha, 4.2 acres) on Ranch $\mathrm{C}$ consisted of standard woven wire (factory designated as 6-35-12-12 1/2) clipped to metal T-posts and topped by two strands of barbed wire (Fence 5). This fence was $110 \mathrm{~cm}(43.5 \mathrm{in}$.) high. The enclosure ( 0.93 ha or 2.25 acres) on Ranch $D$ was constructed of woven wire (9-39-12-12 1/2) topped by only one strand of barbed wire and was also $110 \mathrm{~cm}$ high (Fence 8). Both of the above type fences a re commonly used by Kansas livestock producers for sheep confinement.

The test procedure on both ranches consisted of stocking each woven wire enclosure with 10-20 la mbs and a few ewes and monitoring these sheep for coyote kills. When a minimum of five or more sheep were killed or wounded by coyotes, offset electric wires were strung along the outside of the woven wire fence, the woven and barbed wires were grounded, and all offset wires were charged (see Table 1). Electric wires were installed in the same manner as previously described. The fiberglass $T$-posts were driven about 46 $\mathrm{cm}(18 \mathrm{in}$.) into the ground and positioned opposite and $13 \mathrm{~cm}(5$ in.) out from the metal T-posts holding the woven and barbed wires. The tops of the fiberglass and metal T-posts were fastened to

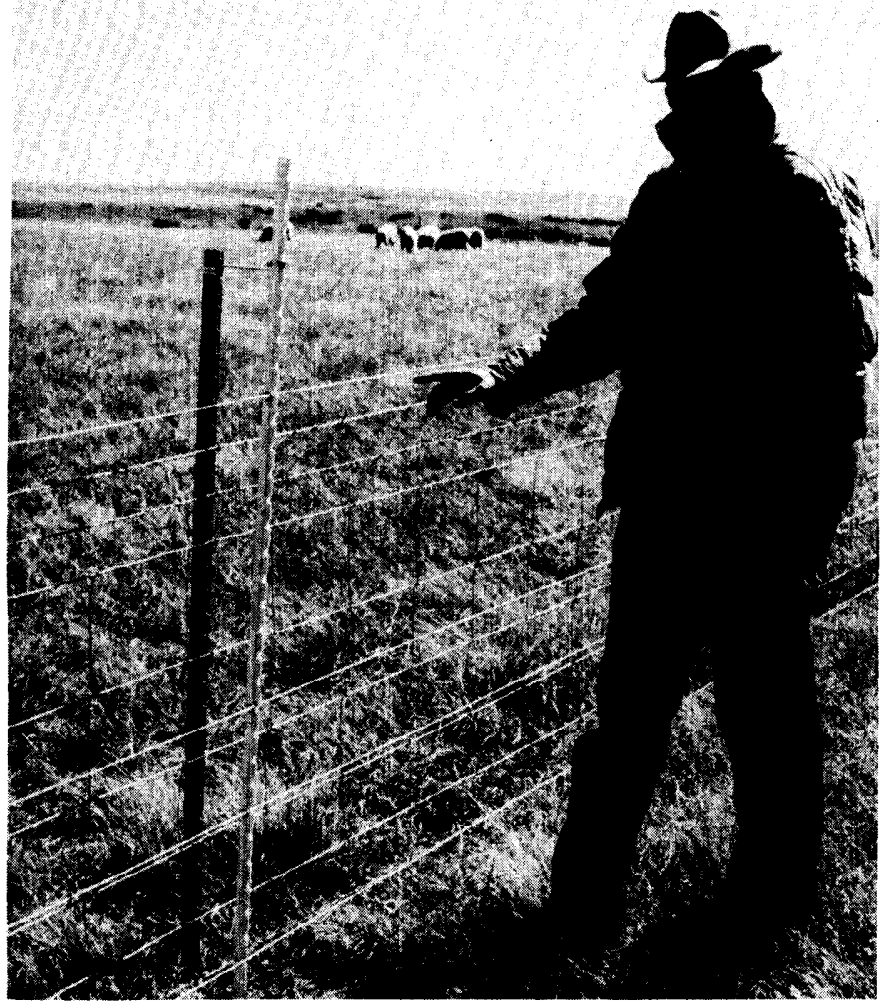

Fig. 2. Four offset wires were added to an existing woven and barbed wire fence in Kansas. It was necessary to add a fifth wire to keep coyotes from entering the enclosure and killing sheep. 
each other with a $0.3 \times 2.5 \times 17.8 \mathrm{~cm}(1 / 8 \times 1 \times 7 \mathrm{in}$.$) cut and bent$ steel bracket clamped to both $\mathrm{T}$-posts with screw-type automotive hose clamps.

Electric wires were positioned as follows: the bottom wire was located at a height to prevent coyotes from going under the fence; the intermediate height wires bisected the bars of the woven wire fence to maximize body contact as coyotes attempted to pass through the fence; and the top electric wire was intended to discourage coyotes from jumping or climbing over the fence (Fig. 2).

Both four (Fence 6) and five (Fence 7) wire configurations were tested on Ranch C. On Ranch D, two (Fence 10) and four (Fence 9) wire installations were evaluated. Sheep confined within fence configurations that effectively excluded coyotes were monitored for 60 days, after which tests were terminated.

\section{Results}

The results of our tests with offset electrified wires a re shown in Figure 3. Sheep on Ranch $\mathrm{C}$ were confined in Fence 5 for 105 days but it was not unitl day 93 that coyotes began killing. The five kills recorded occurred from days 93 through 96 . The four offset electric wires subsequently installed (Fence 6) deterred predation until the 17 th day, when one killed and one wounded lamb were found. A fifth wire was then added to the fence (Fence 7) to block entry between two of the higher woven wire bars and no further kills occurred for the next 60 days.

Nine lambs were killed or wounded in a single night in the woven and barbed wire enclosure (Fence 8 ) on Ranch D. Immediately thereafter we attempted to install electric wires but experienced some technical problems so all surviving sheep were therefore removed from the enclosure.

Twenty-six days later a four electric wire configuration (Fence 9) was erected and the enclosure was again "stocked" with sheep. No coyote kills occurred for 60 days, at which time we removed all four wires to verify that depredating coyotes were still present and given the opportunity, they would attack our sheep. In the absence of electrified wires, coyotes killed 11 sheep within 5 days over an 11-day exposure period. The bottom two wires were then restrung (Fence 10) but 14 days later coyotes entered the enclosure and killed or wounded nine more sheep. We then terminated our test on Ranch D as it was apparent that four wires were required to exclude coyotes and that active killers were on this ranch throughout the entire period of our study.

\section{Sheep Producer Survey}

\section{Methods}

Factors such as fence construction, configuration and maintenance, sheep stocking rates, livestock management practices, topography and vegetation, and severity of predation all influence the efficacy and cost effectiveness of electric fencing. As we lacked time, funds, and personnel to carry out controlled tests to evaluate all these factors, we felt that an interview survey of producers currently using electric fencing would provide some indication as to its usefulness as a coyote management technique. In 1979, we contacted importers and distributors of electric fencing, university wildlife damage extension specialists, and state supervisors of the U.S. Fish and Wildlife's Animal Damage Control Program. From these sources we compiled a list of sheep producers in the west and midwest who were presently using electric fencing to protect their pastured sheep from coyotes. We interviewed 37 ranchers and also obtained limited information regarding cooperative public and privately funded electric fencing ventures in southeastern New Mexico. The interview questionnaire we devised provided information regarding sheep production data, historic predator losses, predation rates with and without electric fencing, predator control efforts by traditional techniques, producer assessment and maintenance of their electric fences, and information on wire spacings and the types of fences installed. At the conclusion of each interview the interviewer ranked each producer's electric fence with respect to adequacy of installation and maintenance, and its apparent effectiveness based on the data he recorded and on visual inspection of
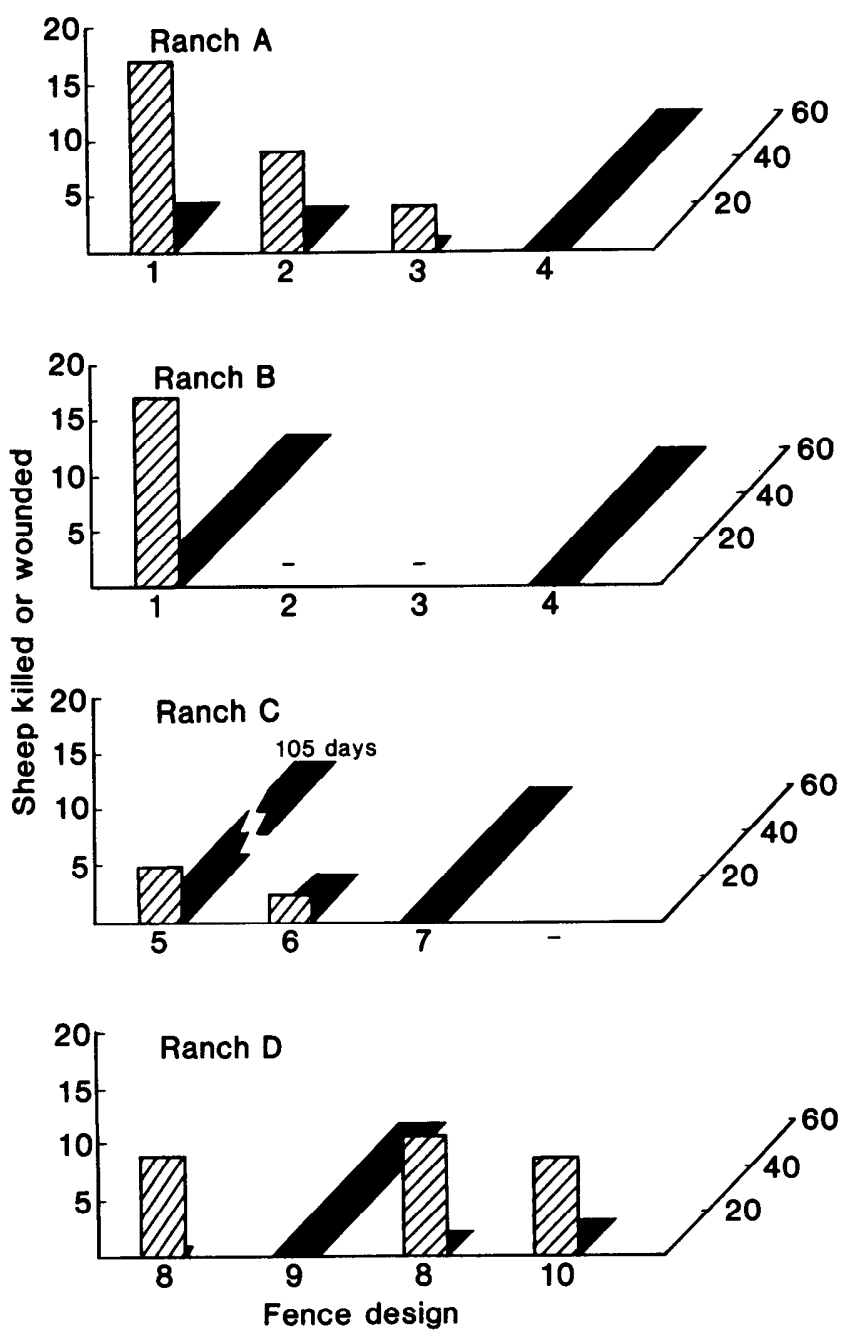

Fig. 3. Results of electric fencing tests in North Dakota and Kansas. Hatched vertical bars indicate the numbers of sheep killed or wounded within each type fence. Solid diagonal bars indicate the length of time sheep were confined within each fence. Tests were terminated when sheep were protected for 60 days (Fences 4, 7, and 9).

the fence.

Fourteen producers were interviewed in California, Oregon, and Washington and 23 in Kansas, Oklahoma, and Texas. The cooperative fencing projects in New Mexico were primarily undertaken to install "drift" fences, many of which were being installed adjacent to public lands. Two of the producers we interviewed were using electric fences to protect sheep in feed lot situations and all but two were using the relatively new Australian and New Zealand techniques, materials, and chargers.

\section{Results}

Some of the producers we interviewed would not or could not respond to all our questions. For example, several had purchased sheep and electric fencing materials simultaneously, and thus were not able to provide information regarding predation losses before and after fences were installed. The number of respondents (i.e., sample size) therefore varied depending upon the specific questions asked.

Of 36 individual producers from whom data were obtained, the mean acreage set aside for sheep production was 2,046 acres or 828 ha (range 50 to 16,800 acres or 20-6,799 ha). The mean number of sheep stocked was 437 ewes and 390 docked lambs. The cooperative electric fencing ventures in New Mexico involved 30-33 ranches and about 416,000 acres or 168,355 ha (650 sections) of deeded or leased land stocked with about 55-58 thousand sheep. Much of their electric fencing, a total of about $150 \mathrm{mi}(241 \mathrm{~km})$, was still being installed and thus little information on effectiveness and 
maintenance was available at the time of our survey.

Eighteen of $35(51 \%)$ individual producers interviewed installed their electric fencing because of predation problems in past years. The remaining 17 had experienced little or no previous predation but erected fences as a preventive measure. Where predator losses had occur red 1-3 years before erecting fences, producers estimated they had lost 3,348 sheep to coyotes, 51 to dogs, and 229 to all other predators ( 200 sheep were reported as lost to eagles by a single rancher).

Nineteen of 25 producers $(76 \%)$ said that predator control was conducted on their ranch 1-3 years before they put up their fences. Only one of these individuals said that he discontinued the use of other control methods following installation of his fence. Sixteen of 25 ranchers $(64 \%)$ stated that their electric fencing had reduced the need for predator control. However, of 20 producers who previously penned their sheep at night, only $5(25 \%)$ discontinued this management practice after their fences were completed. Only 10 of 30 respondents (33\%) said that their sheep management practices had changed since they put up their fences.

All but 3 of 35 respondents $(91 \%)$ stated that they checked their sheep at least once a day and two-thirds of the producers who responded to questions regarding the extent of their predation losses relied upon their memory as opposed to written records.

After evaluating the completed questionnaires, 14 producers seem to have provided adequate information to permit a comparison of predator losses before and after they erected their electric fences or wires. Losses to coyotes by all 14 producers over a combined total of 271 months and 27 lambing seasons totaled 1,064 sheep. Losses after fences or electric wires were installed, over a period of 228 months and 22 lambing seasons, totaled 51 sheep. According to our respondents, this represented a reduction of losses due to coyotes of about $94 \%$.

Only 21 of the 37 individual producers (57\%) obtained "professional" advice (e.g., fencing distributors, county agents) before building fences or adding wires to existing sheep fences. Nineteen producers put up fences consisting entirely of electrified wires (generally with hot and grounded wires alternated), 11 strung electrified offset wires from existing woven wire sheep fences, and 7 producers erected both types of fencing. Thirty-four were being used as perimeter fences, 14 as cross fences, and 3 as drift fences. Seven fences consisted of a single "trip" wire offset about $13-15 \mathrm{~cm}$ (5-6 in.) out from an existing fence and $13-15 \mathrm{~cm}$ up from ground level, 1 producer had only a single charged wire at the top of an existing fence, 3 had both "trip" and top wires, and 28 had multiple strands of electrified wires. Twenty-one of 35 producers $(60 \%)$ said that they experienced some type of maintenance problem. Twentythree of 34 respondents $(68 \%)$ rated their fences as very effective and $11(32 \%)$ as fairly effective for controlling predation. All but 1 or $\mathbf{2}$ of $\mathbf{3 4}$ producers said that their fences were a good investment, that they would install more electric fence or additional wires if future losses were high, and that they would recommend electric fencing as a predator damage control technique to other producers.

\section{Discussion}

Our 1977 field tests in North Dakota showed that an all-electric, 168-cm high, 12-wire fence excluded coyotes. However, further studies are needed to determine the minimum effective height. Our data indicate that this should be somewhere between 76 and 168 $\mathrm{cm}$. These field trials should be conducted in several areas of the west as coyote fence-crossing behavior apparently varies geographically. According to Fish and Wild life Service predator control specialists, coyotes in the southern states generally pass either under or through standard woven-wire sheep fences (M. Caroline, pers. comm.), whereas in the north the great majority jump over such fences (W. Pfeifer, pers. comm.). These observations, while not documented in the literature, are based on numerous sightings of coyotes in or around sheep pastures, tracks left in sand or snow, and coyotes taken in steel traps or snares set in "slide" holes beneath sheep fences. This variation in coyote behavior may be due to frozen ground (making digging difficult) and snow drifted against fences in the north, as opposed to the loose, sandy soils commonly present in many areas of the southwest. Regardless of the reasons for the variation in fence-crossing behavior, lower and less costly electric fences may prove to be effective in the southern states. The use of offset electric wires on woven-wire sheep fences in the north may not be effective unless additional wires are positioned above the existing fence.

One limitation of our preliminary field tests in 1977 and 1978 was the termination of the tests following a 60-day coyote exclusion period. It is well known that coyotes can learn to evade or circumvent various depredation control techniques and the probability of this occurring after prolonged exposure to elect ric fences can only be assessed by conducting long-term field trials.

Only a relatively few farm or semi-farm flock sheep producers have erected electric fences or wires for excluding coyotes from their pastures. Several factors may be responsible: prior experience with some high-impedance chargers shorting out during rainy periods or in weed-choked fence lines, the necessity of removing existing woven wire boundary fences before all-electric fences can be erected, and probably most important, the initial cost of electric fencing materials and installation. As of June 1980, all materials needed (less charger) for constructing 1 mile of a seven-wire "coyote/ dog" fence sold by one distributor was $\$ 1,150$. Materials for 1 mile of our 12-wire fence cost about \$1,580. Material costs for perimeter fencing $1 \mathrm{mile}^{2}$ with the 7-or 12-wire configurations were $\$ 4,330$ and $\$ 5,690$, respectively. Excluding labor costs for installation and assuming a stocking rate of 100 sheep per mile ${ }^{2}$, a market value of $\$ 75$ per sheep, an annual predator loss of $5 \%$, and that the electric fence completely stops predator losses, the cost of fencing materials would be amortized in about 11.5 (7-wire) or 15.0 (12wire) years. A more realistic appraisal of amortization might be to calculate the cost of installing a four-wire electric fence for sheep confinement purposes only and to then consider the additional cost of materials required to build a predator-proof fence. Materials to fence 1 mile $^{2}$ with four wires for sheep confinement was about $\$ 2,420$. The cost difference for materials to build a 7 - or 12-wire fence was $\$ 1,910$ and $\$ 3,270$, respectively. Using the differences in costs and making the same assumptions listed earlier (i.e., $5 \%$ annual loss to coyotes, etc.), the additional material costs for excluding coyotes could therefore be amortized in about 5 and 9 years, respectively. A $10 \%$ annual sheep loss to coyotes would, of course, reduce the years required for a mortization by half, or 2.5 to 4.5 years.

The above calculations and assumptions could also be applied to the installation of offset electric wires, although existing fences must be in reasonably good condition. Alternate and less costly methods for offsetting wires than the one we used can probably be devised but are beyond the scope of this paper. Obviously, each producer will have to consider all relevant factors to determine whether the cost of building elect ric fencing or installing electrified wires will result in a favorable cost-benefit investment.

Our survey of producers using electric fences or wires provided valuable information; however, we wish to emphasize that the data gathered were based in part on opinions and estimates from memory. The favorable producer response was impressive, but from prior experience we also know that psychological factors play an important part in user assessment of animal damage control methods. Furthermore, several of the producers who provided information were franchised to sell electric fencing materials and this may have influenced our data.

We think it important to point out that many of the producers we interviewed felt that while electric fencing or offset electrified wires were of considerable value in deterring predation, they also viewed such fencing as complementing other control techniques such as steel traps, snares, or M-44 devices. Producers often indicated to us that while their fences did not completely exclude 
coyotes from pastures, the fences did limit access and thus make it much easier to determine where to locate lethal control tools. The opinion was also expressed that the efficacy of electric fencing may, at least in part, be a function of pasture size. Coyotes may be able to live and thrive entirely within large fenced pastures and the problem of removing them could be equally as great as if no electric fencing had been installed. This area of concern obviously needs further investigation.

We were not impressed with some of the fences installed by producers. Poorly braced corner posts that shifted and resulted in sagging wires, especially when rain or melted snow softened the earth, were common. Poor grounding and poor insulation of positive-charged wires resulted in low line voltages as measured with our voltmeters. Another shortcoming we noted was a failure to block gullies, water courses, or other depressions with charged drop wires. Finally, we felt that some producers were not inspecting and maintaining their fences as evidenced by broken line posts, wires found lying on the ground, and broken insulators. These deficiencies point out the importance of providing instructional and educational material to producers and the value of knowledgeable extension specialists and demonstration projects.

One problem with our survey was that many of the producers we interviewed had recently installed or were just installing their electric fences. We believe that another survey, conducted after electric fences have been in use for a few years, would be a worthwhile project. Assuming willing cooperators a re available, an alternate approach worth consideration is the close, periodic monitoring of selected ranches on which fences have been erected to assess their effectiveness over a period of several years.

One electric fencing application we were unable to adequately assess was the use of temporary or portable electric fences to exclude predators. Such fences could be a valuable technique for rotational grazing, on leased pastures, or around bedgrounds. We suggest that further studies of this application be undertaken. Finally, field data are not available to permit judgment as to the relative merits of low versus high output impedance chargers and their capability to maintain adequate line voltages under adverse weather and vegetative conditions. Although laboratory tests suggested that low impedance chargers perform better, field tests on identical areas using both types simultaneously with precise measurements of such factors as rainfall, moisture, and fence-line vegetation, should clarify this issue.

Our electric fencing research indicates that this technique has considerable potential for protecting pastured sheep from coyotes, providing fences are properly installed and when a combination of various factors result in a favorable cost-benefit investment for the producer. Intensive and long-term studies a re still needed to clarify such factors as minimum effective heights, wire spacings, relative merits of available equipment, applicability to various sheep management situations, and the ability of coyotes to evade or circumvent electric fences over a period of time.

\section{Literature Cited}

Bowns, J.E. 1976. Field criteria for predator damage assessment. Utah Sci. 37:26-30.

Dorrance, M.J., and J. Bourne. 1980. An evaluation of anti-coyote electric fencing. J. Range Manage. 33:385-387.

Gates, N. 1978. Constructing an effective anticoyote electric fence. U.S. Dep. Agr., Agr. Res. Serv. Leaflet 565. 5 p.

Gates, N.L., J.E. Rich, D.D. Godtel, and C.V. Hulet. 1978. Development and evaluation of anti-coyote electric fencing. J. Range Manage. 31:151153.

Henderson, J. 1978. Electric fence installation. Fence Industry, May, 1978. p. 17-18.

Henne, D.R. 1975. Domestic sheep mortality on a western Montana ranch. M.S. Thesis, Univ. Montana. $53 \mathrm{p}$.

Larson, G.E., M.H. Wallace, J.M. Lewis, and M.E. Mansfield. 1975. Coyote predation in sheep. IIl. Agr. Exp. Sta. DSAC 3, Feb., 1975. p. 101-104.

Rowley, I. 1970. Lamb predation in Australia; incidence, predisposing conditions, and the identification of wounds. CSIRO Wildl. Res. 15:79123.

Shelton, M. 1977. Electric fencing as a means of deterring coyote predation. Ranch Mag. 58:1-3.

Thompson, B.C. 1976. Evaluation of wire fences for control of coyote predations. M.S. Thesis, Oregon State Univ., Corvallis. 59 p.

Thompson, B.C. 1979. Evaluation of wire fences for coyote control. J. Range Manage. 32:457-461.

Wallace, M.H. 1975. Better and cheaper fences for sheep. Ill. Agr. Exp. Sta. DSAC 3, Feb., 1975. p. 105-106.

\section{Four Copies, Please}

Authors submitting manuscripts to the Journal of Range Management a re reminded to send 4 copies instead of the former 3 . The additional copy should expedite the review process. In the case of photographs and figures, xerox copies are adequate for review purposes if the procurring of additional prints would pose a hardship. Manuscripts with insufficient copies will be delayed in Denver until the required copies arrive. 